\title{
THE HISTORY OF MAPPING IN ICELAND, WITH SPECIAL REFERENCE TO GLACIERS
}

\author{
by
}

Haukur Tómasson

(Director, Hydro Power Division, Orkustofun (National Energy Authority), Grensásvegur 9, 108 Reykjavik, Iceland)

\section{ICELAND ON MAPS}

The history of this country, or rather the nation which inhabits it, began about 1100 years ago and the earliest historical account "Íslendingabók", by Ari Fródi, states that Iceland was colonised from Norway during the reign of Haraldur, the fair-haired king of Norway. The country seems to have been fully settled in a few decades and the nation of Icelanders was born. A century later, they extended their settlement and discovered and colonised Greenland. From there, they sailed on to continental America but failed to make a permanent settlement there, as is well known.

One or two centuries before the Norwegian colonisation of Iceland, some Irish hermits and monks had already established some habitations. Still a thousand years earlier, Iceland may have been seen by human eye, when Pytheas of Marseille sailed to the Arctic seas and discovered land, which he named Thule. Whether this was Iceland will never be proved, but this has been a constant argument among scholars and laymen since the existence of Iceland became generally known. It of ten appeared on maps, either as a synonym for Iceland, or as a separate mysterious country, north of the British Isles.

At the time of the settlement, geographical knowledge and interest, as well as cartographic work, was fairly primitive. This was in the dark middle ages. But still there were always some people who tried to arrange their knowledge of the position and shape of countries on sheets of paper, which we call maps. In southern Europe and the Mediterranean, maps were based on old tradition, but, north of the British Isles, no such background existed. The knowledge that, somewhere in the north, there was a land, possibly a large island, was gradually transferred to the cultural centres in Europe and with it the name of Iceland, but it was difficult to distinguish it from other islands such as the Orkneys, Shetlands, Faeroes and Pytheas's Thule. Many maps of this kind exist, dating from the 11 th and 12 th Centuries, most of them from the British Isles, where this area was better known than farther south. But the Arab, Al Idrisi, the most famous cartographer of this time, seems to have had some ideas about this country and, on his map from the year 1154, he shows the island "gazirat Islandia", north of Scotland.

In the 14th century, the first Nordic cartographer, the Dane Claudius Clavus, prepared two maps of north-western Europe. The first one (Figure 1), is shown here in simplified form. This map is a big step forward and contains a great deal of geographical knowledge of the Vikings. Both Iceland and Greenland are shown on this map and the relative position of the northern countries is fairly good land place names are little distorted, except that the latinization of the spelling is evident and remained so for a long time on later maps.

Parallel to the cartography of Claudius Clavus, new kinds of maps developed in Southern Europe. On these maps, the spelling of the name of Iceland became more and more distorted. The name of the country is Ísland and almost the same form is in use in other Scandinavian and Germanic languages. Internationally, the English translation, Iceland, is widely used. The Latin form is Islandia and it is

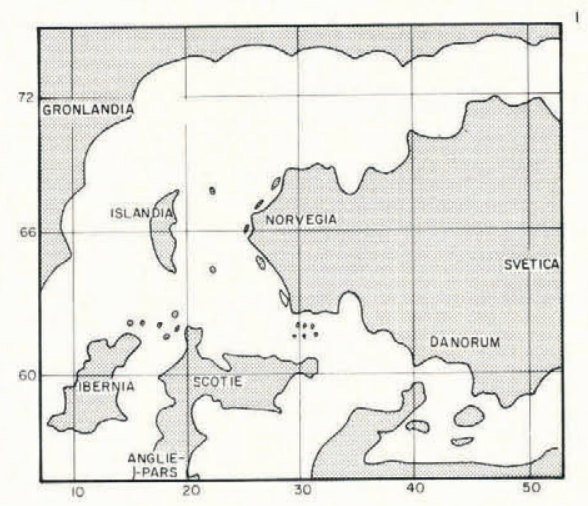

Fig.1. A simplified map, showing the main features of Claudius Clavus' map of 1427. The first Scandinavian map with the Vikings' geographical knowledge.

still generally used in Roman languages, being the most common form on middle age maps. The forms Islanda and Islant also appear. In the late 15 th century, the Latin form gradually became more and more distorted on South European maps first to Ixilandia then Fislanda and Frislanda. The land with the distorted name also tended to move south, as shown on Figure 2.
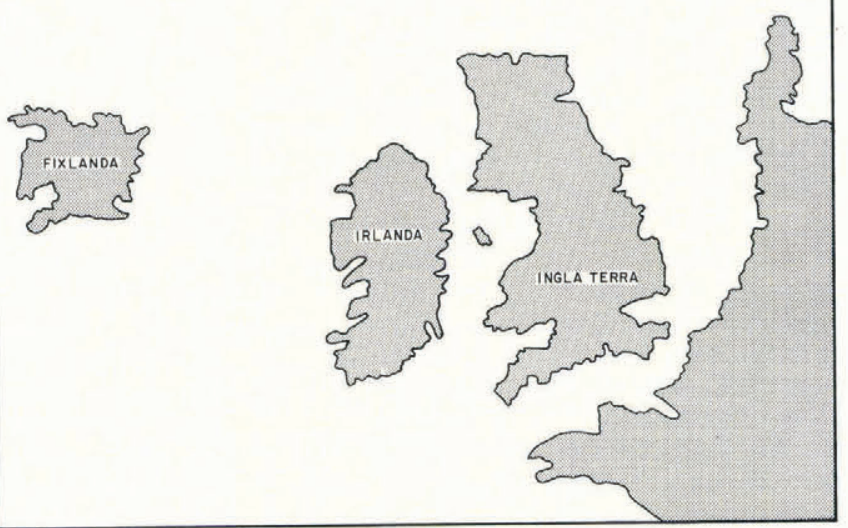

Fig.2. A simplified map, showing the main features of the Fislanda type maps. This is from Portugal from the late 15 th century.

The South European type was not at all the only map. Maps in the tradition of Claudius Clavus were also made and, in the 16th century, maps made in Northern France and in the Netherlands show the location of Iceland and the spelling of the name is much more nearly correct than on the South European maps. In Figure 3, an example of this 


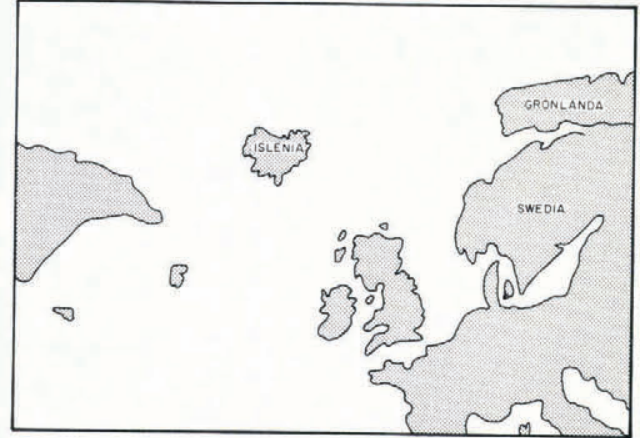

Fig.3. The northern European or Dieppe tradition, from the 16th century. Shows better knowledge of the location and better spelling of the name of Iceland

mapping is shown, in the so-called Dieppe tradition, from the middle of the 16 th century.

In the latter part of the 16th century, there came about a sudden change in the mapping of this part of the world, in that almost all maps started to show the same main features. This seems to have occurred by a merging of the Dieppe and South European traditions. Cartographers no longer identified Frisland as Iceland, but still did not doubt its existence and therefore put both countries on their maps. Figure 4 shows this on a map from 1570. This type of map of the North Atlantic was dominant for a whole century. It is not until the latter half of the 17th century that the strange island, Frisland, disappeared from maps and Iceland ruled the middle of the North Atlantic alone.

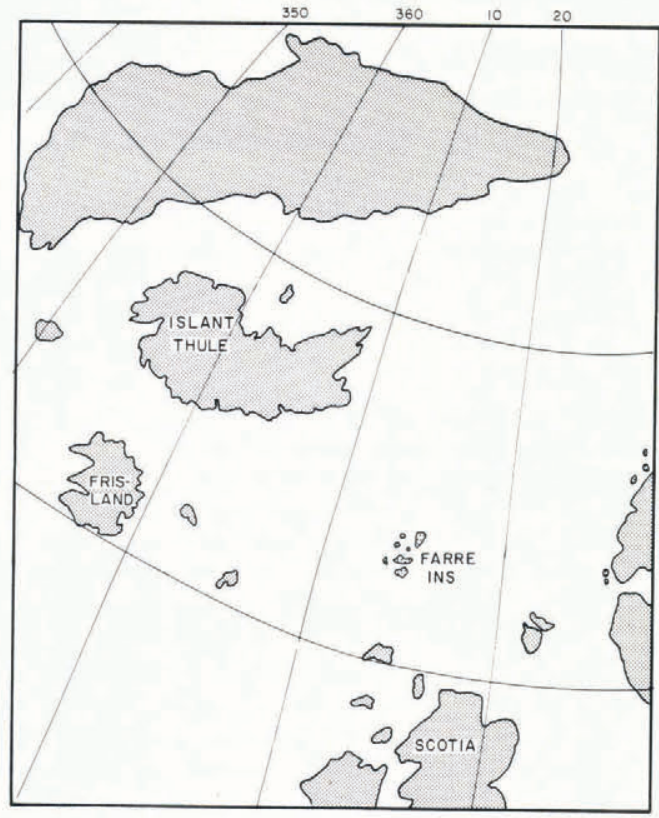

Fig.4. A simplified map showing Iceland and Frisland by Abraham Ortelius (1570).

\section{MAPS OF ICELAND}

These main lines of development in the cartography of the North Atlantic were not without exception. Other quite remarkable maps were also prepared. One of the best known is the map Carta Marina by the Swede, Olaus Magnus, which was published in Venice in 1539. One of the first special maps of Iceland was taken from Carta Marina and published in Paris in 1548. The configuration of the country is far from correct. The episcopal seats, Hólar and Skálholt, and the volcano, Hekla, are shown, but these are the names appearing on most early maps showing Iceland. In addition, a place like Caos is shown, which is linked with superstitious beliefs in Europe about the nature of Iceland.
Half a century later, the first special map of Iceland, based on an extensive knowledge of the country, was published. This map was compiled by Gudbrandur Thorláksson, bishop of Hólar (1542-1627). It was initially published in Antwerp, in 1590 in a geographical edition: Theatri Orbis Terrarum Additamentum IV, by A. Ortelius (see Figure 5 and front cover illustration), and, five years later, in an Atlas, published by Gerard Mercator, in Duisburg. This map shows the main geographical features of the country, such as all the major bays, fjords, and peninsulas, with their proper names, with good spelling in Icelandic. This map also shows geographical coordinates, with the longitude $0^{\circ}$ or $360^{\circ}$ crossing the western part of Iceland and latitudes which show the country too far north. Accordingly, Iceland appears to be too long from east to west, but fairly correct in the north-south direction. This map has a special interest for glaciology, because it is the first map in Europe showing glaciers, with a separate symbol. Maps of the Alps, showing glaciers, did not appear until two decades later. It shows all the main glaciers of Iceland, except Vatnajökull. The name is entirely missing, but a symbol for a small glacier is shown (see Figure 5).

Another interesting feature of this map is the sea ice seen at Langanes. This indicates that drifting polar ice was well known then, as it is now. This also indicates a climate similar to that of today.

The name of Gudbrandur is nowhere mentioned on the map, perhaps because he did not like the publishers' layout. The symbols for all kinds of creatures, drawn on the map, represent the belief of scholars in Europe at that time, already mentioned in connection with Olaus Magnus. Gudbrandur and his relative Arngrimur Lærdi tried to dispel these fantasies.

With the publication of this map, Iceland got a fairly correct position and shape on maps of Europe. It served as a basic reference map for well over a century. Other maps, some of them with certain improvements, were also drawn, but not published. The most notable are maps by Thórdur Thorláksson, bishop of Skáholt, dating from about 1670. (Gudbrandur was great grandfather to Thórdur). These maps include some place names and information not on earlier maps and the position and shape is much more accurate.

In the early 18th century, the authorities in Denmark, which governed Iceland, decided to map the country on a much larger scale than previously. The initiator of the work was Admiral P. Raben, governor of Iceland. He hired an Icelander, Magnús Arason, for this work but, after his accidental death by drowning, a Norwegian, Tómas Hans Henric Knoff, took over and carried out the major part of the work, together with his brother. The mapping took place in the years 1721 to 1734 and the finished maps were published in the next decades. This map is based on a considerable amount of surveying, but a continuous triangulation around the country was not made.

This mapping is a great improvement on older maps. The position and size of the country are fairly accurate, but the shape has obvious defects. Vestfirdir extends too far north and Reykjanes is out of shape. The south coast is shown, for the first time, with relatively correct shape. All the main glaciers, including Vatnajökull, are shown on this map. Vatnajökull is here divided into two parts. Names of glaciers are often confused. Place names are of ten partly translated into Danish, or spelled in the Danish way. This map appeared in various forms in many publications and was the main map of Iceland, well into the 19th century.

The physicist, Sveinn Pálsson (1762-1840), was without doubt one of the most original glaciologists of his time. At the end of the 18th century, he carried out extensive research in natural science in Iceland. He wrote a paper on glaciology, in 1795, in which he explained the movement of glaciers as plastic flow

At this time this theory was not known, not did it fit into the state of knowledge of glaciology in Europe. A.C. Bordier, in France, had come up with this idea 20 years earlier, but the theory was not accepted in scientific circles until the second or third decade of the 19th century.

Sveinn Pálsson wrote his paper in Danish and sent it to the Naturhistoriska Selskabet (the Society of Natural History) in Copenhagen. It was not published and did not 


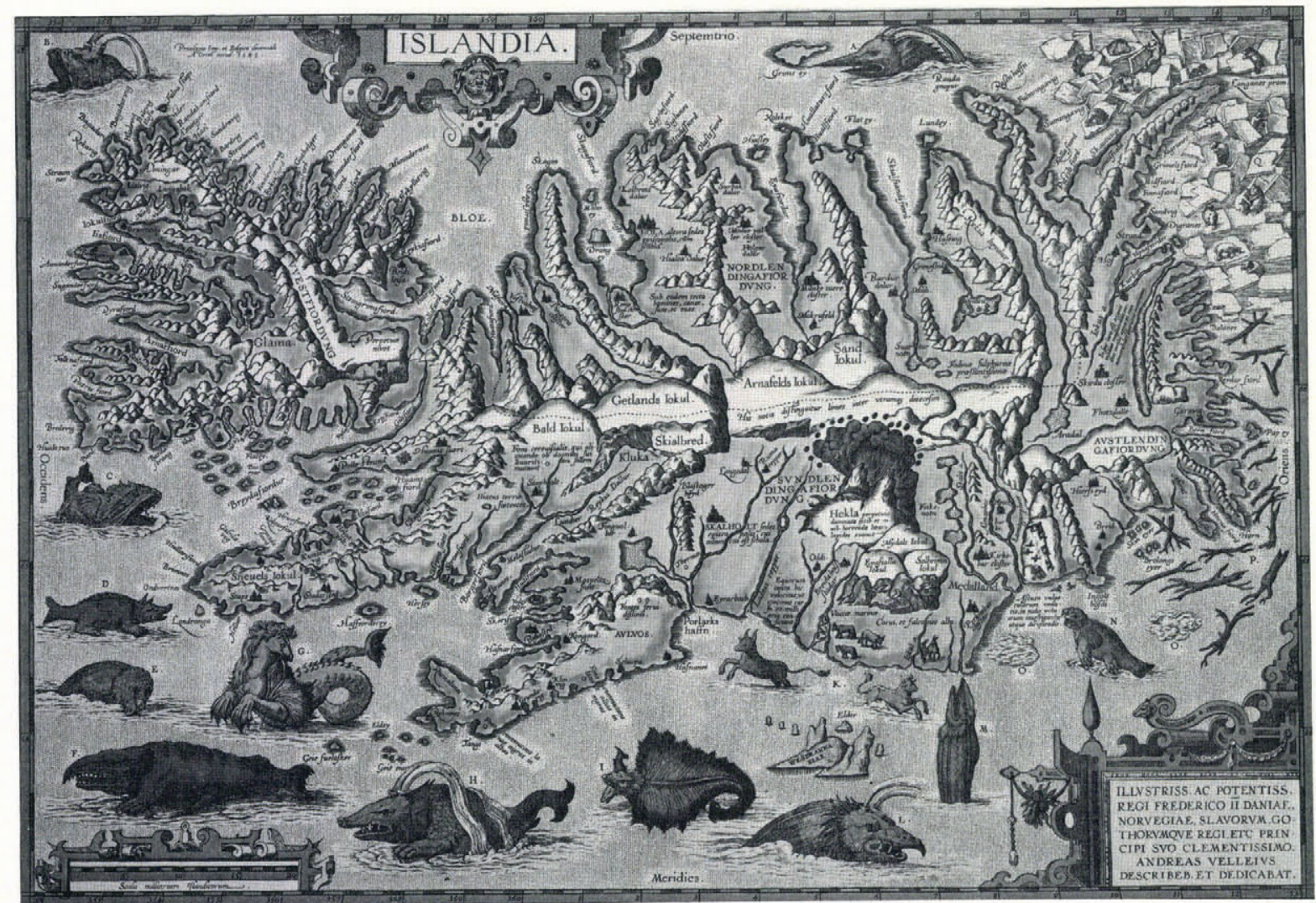

Fig.5. A photograph of Gudbrandur Thorláksson's map of 1590.

appear in print until 1945, in Icelandic. Yet parts of it were published in Oslo in 1883.

Sveinn mapped all the large glaciers and his map of Vatnajökull is especially notable. He used the names Klofaor Vatnajökull and gave most of the names of the outlet glaciers and the glacier-fed rivers. On this map, Vatnajökull is given the size and shape we know from modern maps.

\section{SURVEYED MAPS}

In the beginning of the 19th century, a new large scale mapping was started, initiated by the authorities in Copenhagen. The aim was to create nautical maps of the coastal areas and as far inland as can be seen from sea. This effort, named "coastal survey", was carried out in the years 1801-1815. A triangulation network was now surveyed around the country for the first time, giving it the correct outline on a map. The first maps based on this survey were published by Sjökort Arkivet (Nautical Map Archive) in Copenhagen.

The mapping of Iceland in this period was finished by one man, Björn Gunnlaugsson, teacher at the high school at Bessastadir, our present Presidential residence. He based his survey of the interior on the coastal survey already complete. He carried out his work in the summers of the years 1831-1843 and the maps were published in 1844 by Íslenska Bókmenntafélagid, (Icelandic Literary Society), in Reykjavik and Copenhagen.

The maps were on a scale of 1:480 000 and they show all the main features of the country and mark a great step forward. The longitudes are counted from Copenhagen. On this map, the glaciers are generally shown too large. This map and others based on this survey were in use until the second world war.

\section{MODERN MAPS}

Modern mapping was started in the beginning of this century. The driving force for this mapping was the Icelandic need for better maps, especially nautical ones. The initial funding was provided by the Icelandic Parliament, but later financing came from the Danish state, which paid a greater part of the cost. To begin with, in 1902-14 and
1920, the contractor was Generalstabens Topografiska Avdeling, in Copenhagen. A new triangulation network was surveyed and detail mapping was carried out by a plane-table method on a scale of 1:50 000 and later 1:100 000. The work proved to be much more time-consuming and expensive than originally expected and so was abandoned for a decade.

In 1930, the work was resumed, this time with the Geodetic Institut in Copenhagen as a contractor. At first, the same methods were used as earlier, i.e. plane-table measurements. But the progress was slow and therefore it was decided to finish it with photogrammetry, using oblique aerial photographs. The photographs were taken in 1937 and 1938 by the Danish Air Force. The photogrammetric work was carried out in Copenhagen and was finished in 1944.

This survey provided a map, on a scale of 1:100 000, of the whole country, with contour lines at $20 \mathrm{~m}$ intervals. On the main glaciers, these are called form lines. The maps were published by the Geodetic Institut, in Copenhagen and Reykjavík and later by Landmælingar Íslands (Iceland Geodetic Survey). These maps and others on a smaller scale, based on the same survey, can be purchased in book stores and tourist shops.

These maps gave much more detailed knowledge of the geographical features of the country. In glaciology, the maps are of interest because they show the position of the southern outlet glaciers of Vatnajökull at the time of mapping, which was just after the turn of the century, and the position of glacier snouts in the interior highlands in 1937-38.

The last general mapping covering all Iceland was done by the U.S. Army Map Service, in the year 1948-49. This mapping was photogrammetric and is based on vertical aerial photographs, mainly dating from 1946-47. The map is mostly based on the Geodetic Institut survey, for ground control. The scale is 1:50 000 and the contour interval is $20 \mathrm{~m}$. This mapping was done for the American Army and is stamped "security information". The map is a great improvement with regard to contour form and is widely used in technical and scientific institutions. 
For glaciology, this map is a good reference for the extent of glaciers in the year 1946-47. In the defence treaty between the Icelandic and U.S. governments, or NATO, from 1951, there is a clause about a new revised publication of the A.M.S. maps. It was to be based on new triangulation and extensive ground surveys. This map was to be published in cooperation with the Icelandic Authorities and with Icelandic legend and spelling of names. The work started in 1956 and a few new sheets were published of the south-west corner of Iceland. It has not been continued, probably due to A.M.S. duties elsewhere in the world.

After the second World War and especially after 1960, much technical mapping has been carried out by Icelandic Authorities. Most extensive is that done by Orkustofnun, which has mapped $23000 \mathrm{~km}^{2}$ on a scale of 1:20 000, with $5 \mathrm{~m}$ contour intervals.

In recent years, a systematic mapping of the whole country has been discussed among map users. No progress has yet been made, but the need for better basic maps is evident. All the technical resources to carry out such mapping work are available in the country, both men and instruments.

The photogrammetric mapping of the all-white, higher parts of the glaciers is still a technical problem. The older maps only showed form lines on these areas of the glaciers. But, to draw accurate contour lines, new methods must be introduced. From the abstracts submitted for this symposium, one may conclude that several new methods to map glaciers and their rapid changes may be on the way and this, indeed, is the theme of this symposium: Glacier Mapping and Surveying.

\section{REFERENCES}

Hermannsson H 1931 The cartography of Iceland. Islandica 21

Nørlund N E 1944 Islands kortlægning; en historisk fremstilling. Geodatisk Institut. Publikationer 7

Sigurdsson H 1971 Kortasaga Íslands 1. Reykjavik, Bókaútgáfa Menningarsjóds

Thorarinsson S 1960 Glaciological knowledge in Iceland before 1800; a historical outline. Jökull 10: 1-17 